\title{
THE FELA AND THE JONES ACT: FROM NEGLIGENCE \\ TO ASSAULT AND BATTERY TO FALSE ARREST AND IMPRISONMENT
}

Under the Federal Employers' Liability Act ${ }^{1}$ a railroad worker may recover damages from his employer for injuries caused by the negligence of any of the employer's officers, agents or other employees. A seaman may recover damages from his employer under the Jones Act ${ }^{2}$ in similar situations. "Negligence" in these acts has been interpreted to allow railroad workers and seamen to recover for assaults and batteries by other employees and by third parties. ${ }^{3}$ Relying on this expansion of FELA and Jones Act negligence, the District of Columbia Circuit recently held in Slaughter v. Atlantic Coast Line $R . R .4$ that a railroad worker may recover from his employer under the FELA if a railroad inspector in fact caused his false arrest and imprisonment. 5 In

135 Stat. 65 (1908), as amended, 36 Stat. 291 (1910), as amended, 53 Stat. 1404 (1939), 45 U.S.C. $\$ \S 51-60$ (1958). "Every common carrier by railroad while engaging in commerce between any of the several States ... shall be liable in damages to any person suffering injury while he is employed by such carrier in such commerce, or, in case of the death of such employee, to his or her personal representative, for the benefit of the surviving widow or husband and children of such employee... for such injury or death resulting in whole or in part from the negligence of any of the officers, agents, or employees of such carrier, or by reason of any defect or insufficiency, due to its negligence, in its cars, engines, ... or other equipment." 53 Stat. 1404 (1939), 45 U.S.C. § 51 (1958).

2 Merchant Marine Act of 1920, § 33, 41 Stat. 1007, 46 U.S.C. § 688 (1958). "Any seaman who shall suffer personal injury in the course of his employment may, at his election, maintain an action for damages at law, with the right of trial by jury, and in such action all statutes of the United States modifying or extending the common-law right or remedy in cases of personal injury to railway employees shall apply; and in case of the death of any seaman as a result of any such injury the personal representative of such seaman may maintain an action for damages at law with the right of trial by jury, and in such action all statutes of the United States conferring or regulating the right of action for death in the case of railway employees shall be applicable."

3 For an annotation of FELA and Jones Act assault and battery cases, see Annot., 33 A.L.R.2d 1295 (1954). The damages awarded in these cases have been for injuries consequential to batteries, even though the cases refer to injuries from assaults. Technically, an assault is "an act intended to put another person in apprehension of an immediate battery (a bodily contact, either harmful or offensive) and which succeeds in causing an apprehension of such battery in the other. ... The interest which receives protection ... is the interest in freedom from apprehension of a harmful or offensive contact." 1 HARPER \& JAMES, TORTS $\$ 3.4$ (1956). It is apparent from a reading of the cases that the courts are not concerned with either the technical assult or the technical battery. They are concerned, rather, with the physical injuries and economic loss consequent upon a battery.

4302 F.2d 912 (D.C. Cir.), cert. denied, 371 U.S. 827 (1962).

5 RESTATEMENT, TORTS $\S 35$, (1934), defines false arrest and imprisonment as follows: "(1) An act which, directly or indirectly, is a legal cause of a confinement of another within boundaries fixed by the actor for any time, no matter how short in duration, makes the actor liable to the other irrespective of whether harm is caused to any legally protected 
reaching this conclusion the court asserted that the Third Circuit, in Forgione v. United States, ${ }^{6}$ erred by not allowing an action for false arrest and imprisonment under the Jones Act.

Before the enactment of the FELA, negligently injured railroad workers had the rights of other common-law suitors. These rights were limited, as were the rights of all other common-law suitors, by the defenses of contributory negligence and assumption of risk. The rule that employees assumed the risk of injury from torts committed by their fellow servants effectively nullified their common-law rights, since their chances of obtaining a collectable judgment were small where an action was not available against the employer. 7 The FELA did not add to the rights of railroad workers; it merely eliminated or modified common-law defenses in negligence actions against employers. 8 Therefore, "negligence" as employed in the FELA should be taken as having the same meaning as common-law negligence and thus should not include either assault and battery or false arrest and imprisonment.

Before the passage of the Jones Act injured seamen had a right to main-

interest of the other, if (a) the act is intended to confine the other or a third person, and (b) the other is conscious of the confinement, and (c) the confinement is not consented to by the other, and (d) the confinement is not otherwise privileged."

6202 F.2d 249 (3d Cir.), cert. denied, 345 U.S. 966 (1953). The court in Forgione acknow1edged that FELA and Jones Act negligence had been expanded to include assaults and batteries. It found, however, that the tort of false arrest and imprisonment was sufficiently different from the tort of assault and battery to warrant its exclusion from FELA and Jones Act liability. Id. at 252. The differences among these torts, particularly when viewed in the context of the purposes of the two acts, are fundamental to the thesis of this comment.

7 For a discussion of the rise and demise of the fellow servant rule, as well as a general discussion of the history of employers' liability acts and workmen's compensation acts, see DODD, ADMINISTRATION OF WORKMEN's COMPENSATION 1-26 (1936). Dodd contends that the rule of respondeat superior had been well established by the beginning of the nineteenth century and that the famous cases of Priestley v. Fowler, 3 M. \& W. 1 (Ex. 1837), and Farwell v. Boston \& Worcester R. R., 45 Mass. (4 Met.) 49 (1842) (Shaw, J.) created the fellow servant exception to the well established rule. This historical interpretation is criticized in Pound, Economic Interpretation of Torts, 53 HARv. L. REv. 365 (1940). Although Dean Pound does not choose to quarrel with the extension of the rule of respondeat superior in an industrial society, he does dispute the notion that the principle of respondeat superior was well established before the Priestley and Farwell cases. According to this view the fellow servant rule is not an exception to a well established rule but rather is a refusal to extend a quite limited rule. The differences in historical interpretation are important. The interpretation that the rule of respondeat superior was well established encourages the view that once the fellow servant exception is abolished regard for judicial precedent requires the application and the logical extension of the rule of respondeat superior. The interpretation offered by Pound implies that the removal of the fellow servant limitation to the rule of respondeat superior should not, by itself, extend the coverage of the rule. If the rule is to be extended then the policy of the rule must be the basis of the extension. See Holmes, Agency (pts. 1-2), 4 HARV. L. REV. 345, 5 id. 1 (1891).

853 Stat. 1404 (1939), 45 U.S.C. $\$ \S 52,54$ (1958). The 1908 enactment had only eliminated the defense of assumption of risk in cases in which the violation of a safety statute contributed to the injury. 35 Stat. 66 (1908). See also H.R. REP. No. 1386, 60th Cong., 1st Sess. (1908); S. ReP. No. 460, 60th Cong., 1st Sess. (1908). 
tenance and cure and to indemnity if their injuries were caused by unseaworthiness. They had no right, however, to indemnity for injuries caused by the negligence of either master or crew. 9 In order to provide a negligence action for seamen Congress enacted the Jones Act employing the "odd expedient" of granting to seamen the same rights of action made available to railway workers by the Federal Employers' Liability Act.10 Jones Act litigation, therefore, involves interpretation of the FELA, albeit in the context of a maritime situation. Although the definition of duty might be broader under the Jones Act than under the FELA,11 the definition of negligence should be the same as the common-law standard which would be applied if the FELA is properly construed.

Since the inclusion of false arrest and imprisonment within the statutory definition of negligence was based on the prior inclusion of assault and battery, it is necessary to determine how assault and battery has been incorporated into the two acts in the face of the seemingly clear references to commonlaw negligence. It is misleading, however, to discuss the FELA and Jones Act assault and battery cases as if they were all of one kind. For in fact courts have employed two theories in the process of incorporating assault and battery into the acts. The inclusion of false arrest and imprisonment, however, rests on only one of the two theories.

One theory used to justify FELA and Jones Act liability for assault and battery is based upon the employer's common-law duty to provide a safe place to work. This duty may be breached by negligently failing to protect workers from the assaults and batteries of third parties 12 or, more typically, by negligently hiring a dangerous employee.13 Many courts have been reluctant to find liability under this theory of negligent employment and have placed limitations upon it. Negligent employment involves two elements: The hiring, an act of the employer; and the assault and battery, an act of the employee. The courts that have limited the negligent employment doctrine have done so by requiring that the assailant intend to fur-

9 Chelentis v. Luckenbach, 247 U.S. 372 (1918) (general maritime law); The Osceola, 189 U.S. 158 (1903) (general maritime law).

10 GLMORE \& BLACK, ADMIRALTY 296 (1957). The authors note that Congress apparently paid little attention to the special problems of seamen.

11 "Congress did not mean that the standards of legal duty must be the same by land and sea." Cortes v. Baltimore Insular Line, 287 U.S. 367, 377-78 (1932) (Cardozo, J.). The incorporation of the FELA into the Jones Act has created difficulties in statutory interpretation. E.g., Kernan v. American Dredging Co., 355 U.S. 426 (1958).

12 Lillie v. Thompson, 332 U.S. 459 (1947) (per curiam).

13 E.g., Davis v. Green, 260 U.S. 349 (1922) (FELA) (Holmes, J.); Shepard v. New York, N.H. \& H. R.R., 300 F.2d 129 (2d Cir. 1962) (FELA); Sheaf v. Minneapolis, St. P. \& S. Ste. M. Ry., 162 F.2d 110, 114 (8th Cir. 1947) (FELA); Kyriakos v. Goulandris, 151 F.2d 132 (2d Cir. 1945) (Jones Act); Koehler v. Presque-Isle Transp. Co., 141 F.2d 490 (2d Cir.) (Frank, J.), cert. denied, 322 U.S. 764 (1944) (the leading Jones Act negligent employment case.) 
ther his employer's interests by his actions, 14 a requirement that goes not to the hiring but to the assault and battery. In recent decisions, however, other courts have found liability without regard to the assailant's intent, thereby imposing strict liability for the violent acts of negligently hired employees. 15

A second theory of liability for injuries caused by assaults and batteries considers them as within the definition of negligence in the two acts. 16 This theory is applied to situations in which the employer exercised due care in employing the assailant. The equation of assault and battery with negligence has not been complete, however. Here too, courts have sought to set special limits on employers' liability for assaults and batteries, again by requiring that the employee committing the tort must have intended to further his employer's interests.

The holding that false arrest and imprisonment are actionable under the FELA is based on the second theory of assault and battery liability, the theory that assault and battery is equivalent to statutory negligence. The court in Slaughter composed a syllogism to support its result: Assault and battery, an intentional tort, is FELA and Jones Act negligence; false arrest and imprisonment, because it is an intentional tort, is like assault and battery; therefore, false arrest and imprisonment is FELA and Jones Act negligence. An appraisal of both premises is central to a discussion of false arrest and imprisonment under the two statutes.

\section{I}

It is helpful to begin with the doctrine that a railroad or a shipowner is liable to employees injured by assaults and batteries because of its negligent failure to provide a safe place to work. Although this doctrine is not used as the basis for false arrest and imprisonment liability, it illuminates by contrast the premise of the Slaughter argument that assault and battery is statutory negligence. Furthermore, although the theory of breach of duty to provide a safe place to work is properly distinct from the theory that assault and battery is statutory negligence, courts have not always completely separated the two theories.

The first major treatment of FELA liability for assault and battery appeared

14 E.g., Davis v. Green, supra note 13; Sheaf v. Minneapolis, St. P. \& S. Ste. M. Ry., supra note 13; Lanners v. Atchison Top. \& S. Fe. R.R., 344 Ill. App. 123, 99 N.E.2d 705 (1951) (FELA); Young v. New York Cent. R.R., 88 N.E.2d 220 (Ohio Ct. App. 1949), cert. denied, 339 U.S. 986 (1950) (FELA).

15 Shepard v. New York, N.H. \& H. R.R., 300 F.2d 129 (2d Cir. 1962) (FELA); Cuddy v. Western Maryland Ry., 210 F. Supp. 750 (M.D. Pa. 1962); Najera v. Southern Pac. Co., 191 Cal. App. 2d 634, 13 Cal. Rptr. 146 (1961) (FELA); Tatham v. Wabash R.R., 412 Ill. 568, 107 N.E.2d 735 (1952) (FELA) (Schaefer, J.). There has never been a requirement under the Jones Act that a negligently employed seaman intend to further his employer's interests. See Jones Act cases cited note 13 supra.

16 E.g., Jamison v. Encarnacion, 281 U.S. 635 (1930); Alpha S.S. Corp. v. Cain, 281 U.S. 643 (1930). 
in Davis v. Green, 17 the source of many of the difficulties in subsequent litigation involving the breach of the duty to provide a safe place to work. In the Davis case the administratrix of a conductor who was shot and killed by an engineer alleged that the railroad negligently employed the engineer. The Supreme Court reversed the judgment against the railroad. Mr. Justice Holmes commented:

The ground on which the Railroad Company was held was that it had negligently employed a dangerous man with notice of his characteristics, and that the killing occurred in the course of the engineer's employment. But neither allegations nor proof present the killing as done to further the master's business, or as anything but a wanton and wilful act done to satisfy the temper or spite of the engineer. Whatever may be the law of Mississippi, a railroad company is not liable for such an act under the statutes of the United States. The only sense in which the engineer was acting in the course of his employment was that he had received an order from Green [the deceased] which it was his duty to obey-in other words that he did a wilful act wholly outside the scope of his employment while his employment was going on. We see nothing in the evidence that would justify a verdict unless the doctrine of respondeat superior applies.18

The last quoted sentence reflects Holmes' concern that the employer's liability for an employee's assault and battery of another employee might be based on a fictionalized identification of employer and assailant.19 Holmes believed that the rule of respondeat superior lacked "good sense," 20 and it can be assumed that he was reluctant to hold an employer liable where the statute did not clearly compel him to do so. His device for limiting liability was to require that a relationship be established between the negligent act of the employer in hiring the assailant and the intentional act of the assailant. Unfortunately, he couched this relationship in the traditional language of respondeat superior by requiring allegation and proof that the negligently hired employee intended to further his employer's interests. The consequence of the use of Holmes' device has been to limit, until recently, the growth of FELA liability for breach of the duty to provide a safe place to work.21 Only rarely can an employee committing an assault and battery be said to have intended to further his employer's interests.

17260 U.S. 349 (1922) (FELA).

18260 U.S. at $351-52$.

19 In a similar and subsequent case Holmes commented: "In view of the decision in Davis v. Green ... the plaintiff did not attempt to hold the petitioner liable as principal in the act, but relied upon its failure to prevent the death." Atlantic Coast Line R.R. v. Southwell, 275 U.S. 64, 65 (1927).

20 "[T] he whole outline of the law [of agency] is the resultant of a conflict at every point between logic and good sense-the one striving to work fiction out to consistent results, the other restraining and at last overcoming that effort when the results become too manifestly unjust." Holmes, Agency, 4 HARv. L. Rev. 345, 346 (1891).

${ }^{21}$ See authorities cited note 14 supra. 
Interestingly, however, Holmes' device never limited the growth of a similar liability under the Jones Act.22 FELA cases limiting liability for negligent employment to assaults and batteries intended to further an employer's interests have been distinguished in Jones Act litigation on the basis that "the obligation of a shipowner to his seamen is substantially greater than that of an ordinary employer to his employees." 23 Conversely, this distinction has been used to limit the applicability of Jones Act precedents to FELA litigation. ${ }^{24}$

Recent FELA decisions have freed the action for breach of duty to provide a safe place to work from the requirement that the assailant intend to further his employer's interests. ${ }^{25}$ The major change occurred in Lillie v. Thompson, ${ }^{26}$ where the Supreme Court allowed a young female railroad employee to recover for a nighttime assault and battery by a non-employee on the theory that the railroad negligently failed to protect her from outsiders. Since the outsider could scarcely be said to have been furthering the interests of the employer, it can be said that the Court eliminated the furtherance requirement as a limitation on liability. Although some courts have attempted to distinguish the Lillie case, ${ }^{27}$ allegations of negligent employment have survived demurrer despite failure to claim that assailants intended to further their employers' interests. 28

It now appears that there are situations in which employers under the FELA and the Jones Act bear the risk that employees will be injured by assaults and batteries committed by either third parties or other employees. As a California court recently observed: "On the assembly line or in the railroad shop an adjacent known psychotic employee is no less dangerous than an adjacent known unsafe machine." 29 By focusing on the employer's negli-

22 See Jones Act authorities cited note 13 supra.

23 Koehler v. Presque-Isle Transp. Co., 141 F.2d 490, 492 (2d Cir. 1944). The action for unseaworthiness provides relief for seamen injured by the breach of the shipowner's duty to provide a safe place to work. The concept of a safe place to work, and consequently the doctrine of unseaworthiness, have been expanded so that strict liability has been imposed for the assaults and batteries of a seaman unequal in disposition and temperament to the ordinary seaman. The function of the Jones Act action for negligent employment has therefore been performed by the action for unseaworthiness. E.g., Boudoin v. Lykes Bros. S.S. Co., 348 U.S. 336 (1955); Walters v. Moore-McCormack Lines, Inc., 309 F.2d 191 (2d Cir. 1962); Jones v. Lykes Bros. S.S. Co., 204 F.2d 815 (2d Cir. 1953) (L. Hand, J.); Keen v. Overseas Tankship Corp., 194 F.2d 515 (2d Cir. 1952) (L. Hand, J.).

24 E.g., Sheaf v. Minneapolis, St. P. \& S. Ste. M. Ry., 162 F.2d 110 (8th Cir. 1947) (FELA):

25 See authorities cited note 15 supra.

26332 U.S. 459 (1947) (per curiam).

27 E.g., Young v. New York Cent. R.R., 88 Ohio App. 352, 88 N.E.2d 220 (1949), cert. denied, 339 Ü.S. 986 (1950) (FELA).

28 See authorities cited note 15 supra.

29 Najera v. Southern Pac. Co., 191 Cal. App. 2d 634, 648-49, 13 Cal. Rptr. 146, 156 (1961) (FELA). 
gence in failing to provide a safe place to work, courts have allowed recovery for some assaults and batteries, an appropriate development of common-law concepts. In contrast to this development is the gross manipulation of commonlaw concepts and statutory language that has produced the notion that assault and battery is of itself negligence under the FELA and the Jones Act.

II

The liability of railroads and shipowners under the FELA and Jones Act for the assault and battery of one employee by another, apart from breach of the duty to provide a safe place to work, was not considered until the Supreme Court decided the cases of Jamison v. Encarnacion ${ }^{30}$ and Alpha S.S. Corp. v. Cain. 31 The Court held that an assault and battery "committed in the course of the discharge of his duties and in furtherance of the work of the employer's business" 32 was negligence within the meaning of the two acts. These cases are crucial since they are the basis for the court's opinion in Slaughter that false arrest and imprisonment are negligence within the meaning of the FELA and consequently within the meaning of the Jones Act.

In Jamison the foreman for an employing stevedore struck and injured a longshoreman ${ }^{33}$ working on a Brooklyn pier. The longshoreman alleged that both he and the foreman were employed by the employing stevedore, that the foreman committed an assault and battery upon him and that he was injured. 34 There was evidence that the foreman might have been attempting to get the longshoreman to work faster. The Appellate Division of the New York Supreme Court, although finding that the evidence supported a conclusion that the assault and battery was committed in furtherance of the employ-

30281 U.S. 635 (1930).

31281 U.S. 643 (1930).

32 Jamison v. Encarnacion, 281 U.S. at 641.

33 A stevedore (longshoreman) had been held to be a seaman for the purposes of the Jones Act. International Stevedoring Co. v. Haverty, 272 U.S. 50 (1926) (Holmes, J.). Within a year after this decision Congress adopted the Longshoreman's and Harbor Worker's Compensation Act, 44 Stat. 1424 (1927), 33 U.S.C. $\$ \S 901-50$ (1958). Encarnacion's injuries were incurred in 1925 . Therefore, although the act was in effect when the case was litigated the stevedore could not apply for workmen's compensation. It had been the law of New York for a number of years that a workman should be compensated for injuries caused by assaults and batteries, including horseplay, by fellow employees. Leonbruno v. Champlain Silk Mills, 229 N.Y. 470, 128 N.E. 711 (1920) (Cardozo, J.); Verschleiser v. Joseph Stern Son, Inc., 229 N.Y. 192, 128 N.E. 126 (1920). It is probable, although not certain, that the longshoreman would have been compensated under the Harbor Worker's or state workmen's compensation acts, and it is likely that the New York Court of Appeals was aware of this possibility. The issue of recovery under the Longshoreman's and Harbor Worker's Compensation Act for assaults and batteries by fellow employees was soon decided favorably for injured employees. Hartford Acc. \& Indem. Co. v. Cardillo, 112 F.2d 11 (D.C. Cir.) (Rutledge, J.), cert. denied, 310 U.S. 649 (1940). The availability of relief under workmen's compensation should be considered as a possible influence on FELA and Jones Act assault and battery cases.

${ }^{34}$ Record, pp. 13-14, Jamison v. Encarnacion, 281 U.S. 635 (1930). 
er's work, reversed the judgment for the plaintiff 35 on the ground that the case of Gabrielson v. Waydell36 barred recovery. In that case a captain committed an assault and battery upon a seaman, but the shipowner was found not liable on the theory of the fellow servant rule. The court held that since the Jones Act was predicated on common-law negligence, its enactment had not diminished the precedential value of the Gabrielson case. The Court of Appeals reversed the judgment of the Appellate Division and affirmed that of the trial court, 37 holding that the Gabrielson decision should not be followed. The New York court found that the Gabrielson holding was out of harmony with the FELA which had abolished the fellow servant rule as applied to negligent torts and, hence, was also out of harmony with the Jones Act. In effect, Congress was considered to have discredited the use of the fellow servant rule as a defense in intentional as well as negligent tort actions. The language of the court on this point is instructive:

Reading Gabrielson v. Waydell (supra) in the light of the Merchant Marine Act and its history, we do not hesitate to say that the authority of the case as a rule of maritime law has been largely, if not fully spent; that we should not waste time in pointing out distinctions between negligence and misconduct in this connection in order to defeat plaintiff's recovery but should hold broadly that Congress, in doing away with the fellowservant rule in cases of negligence coming within the scope of its legislation, has left neither substance nor reason to our earlier decision and that it is no longer controlling. 38

The New York court did not decide the case under the Jones Act, but rather used it as a basis for a policy argument against the continued use of the fellow servant rule in common-law or admiralty actions for assault and battery. ${ }^{39}$ The Supreme Court, however, failed to comprehend this and read the New York opinion as applying the Jones Act.40 In affirming the judgment below the Court argued that "it would be unreasonable and in conflict with the purpose of Congress to hold that the assault, a much graver breach of duty, was not negligence within the meaning of the act." 41 In this decision,

35 Encarnacion v. Jamison, 224 App. Div. 260, 230 N.Y.S. 16 (1928).

36135 N.Y. 1, 31 N.E. 969 (1892).

37 Encarnacion v. Jamison, 251 N.Y. 218, 167 N.E. 422 (1929).

38 Id. at 223,167 N.E. at 423.

39 Further indication that the New York court was only using the Jones Act for the purpose of changing non-statutory law may be found in the court's restatement of the injured longshoreman's argument: "The learned counsel for the appellant with admirable candor concedes that no fault can be found with the court below for adhering to the rule as thus stated, but he asks this court to change the law 'to establish a better rule of conduct and give place to a higher degree of justice." "Id. at 221. It would not be necessary to ask the New York court to change the law if Congress itself had changed the law.

40 Jamison v. Encarnacion, 281 U.S. at 638.

41 Id. at 641. 
the Court not only misread the language of the act but also the opinion of the New York court.

In Alpha S.S. Corp. v. Cain, a companion case involving a shipboard assault and battery committed by a superior officer allegedly in an effort to get a subordinate to work, the Supreme Court held that the Jones Act applied. In order to reach this conclusion the Court had to disregard the treatment of the problem in the Second Circuit, where the court had applied general maritime law rather than the statute. 42 The Second Circuit discussed the problem of whether or not the rule of respondeat superior, as applied to assaults and batteries, was part of the general maritime law. 43 It concluded that the rule should be applied. Judge Swan wrote:

The maritime law, no less than the common law, is not incapable of growth by judicial decision. Changes in conditions under which commercial shipping is conducted, as well as changes in economic notions of where loss suffered in the course of a business should fall, should be reflected in the action of the courts, though it result in filling pages which history left blank. Absence of precedent did not preclude recognition by the common-law courts of the modern view that a principal should answer for the willful torts of his servant committed in the furtherance of his master's business. The principle is equally applicable to the business of shipping. . . .44

The result under the approach of both the Supreme Court and the Second Circuit is liability. The Second Circuit arrived at its result by expanding common-law concepts that are appropriately developed by courts. The Supreme Court arrived at its result by doing violence to the language of a statute.

The Supreme Court decided that an assault and battery, committed in furtherance of the employer's business, by one employee upon another is negligence under the FELA and the Jones Act even though there was neither allegation nor proof of the breach of a common-law duty. This was done by incorporating into the act the common-law rule of respondeat superior, the rule used as the basis of the lower court decisions in Jamison and Alpha S.S. Corp. Thus the Court created the difficulties discussed in the next section.

\section{III}

Although the policy behind an extension of a railroad's or a shipowner's liability for the assaults and batteries of its employees may be sound, applica-

42 "While the plaintiff's cause of action cannot, in our opinion, be rested upon the Jones Act (compare Encarnacion v. Jamison), which by incorporating the Federal Employers' Liability Act requires negligence as the foundation of liability [citation omitted], the statutes may appropriately be referred to as showing the legislative tendency [regarding the fellow servant exception] already mentioned." Alpha S.S. Corp. v. Cain, 35 F.2d 717, 721 (2d Cir. 1929).

43 The New York court in Jamison had assumed that the rule of respondeat superior applied and only dealt with the removal of a possible defense or exception to that rule. The Second Circuit dealt directly with the applicability of the rule.

44 Alpha S.S. Corp. v. Cain, 35 F.2d at 722. 
tion of the particular rationale used by the Supreme Court and the lower courts in Jamison and Alpha S.S. Corp. often renders the policy ineffective. Furthermore, the requirement that the assault and battery be committed in furtherance of the employer's business often leads to results inconsistent with one another as well as being out of harmony with the policy. The purpose of this section will be to indicate some of the difficulties created by the Supreme Court's interpretation of the FELA and the Jones Act.

Railroad workers and seamen have received favorable appellate court consideration in only five FELA and Jones Act assault and battery cases litigated on the theory of the Jamison case. 45 In all of these cases the issue on appeal was the sufficiency of the evidence supporting the allegation that the assault and battery was intended to further the employer's business. Similarly, in nearly all cases in which appellate court determinations were favorable to the defendant railroads and shipowners the issue on appeal involved the sufficiency of the evidence to support that allegation. 46

The fact that, with only one exception, 47 every important FELA or Jones Act assault and battery case since Jamison and Alpha S.S. Corp. has involved the sufficiency of evidence might give the impression that the rules of liability are well settled. Such an impression would be false. The rules of liability are uncertain and their consistent application nearly impossible. The major difficulty is encountered in determining whether the assault and battery is committed in furtherance of the employer's business. To determine this the intention of the assailant is generally appraised and the relationship between the

45 In four of these cases defendant-appellants alleged that the trial courts erroneously refused to direct verdicts for them: Pittsburgh S.S. Co. v. Scott, 159 F.2d 373 (6th Cir. 1947) (Jones Act); Baker v. Chicago, B. \& Q. R.R., 327 Mo. 986, 39 S.W.2d 535 (1931) (FELA); Gibson v. Kennedy, 23 N.J. 150, 128 A.2d 480 (1957) (FELA); Jester v. Southern R.R., 204 S.C. 395, 29 S.E.2d 768, cert. denied, 323 U.S. 716 (1944) (FELA). In one case, the appellate court ruled that the trial court erred in directing a verdict for the shipowner. Nelson v. American West-African Line, Inc., 86 F.2d 730 (2d Cir.) (L. Hand, J.), cert. denied, 300 U.S. 665 (1937) (Jones Act). Compare authorities cited in note 14 supra.

46 Copeland v. St. Louis-S.F. Ry., 291 F.2d 119 (10th Cir. 1961) (FELA); Smith v. Lehigh Valley R.R., 174 F.2d 592 (2d Cir. 1949) (FELA); Brailas v. Shepard S.S. Co., 152 F.2d 849 (2d Cir.), cert. denied, 327 U.S. 807 (1946) (Jones Act); Lykes Bros. S.S. Co. v. Grubaugh, 128 F.2d 387 (5th Cir.), modified, 130 F.2d 25 (5th Cir. 1942) (Jones Act); Yukes v. Globe S.S. Corp., 107 F.2d 888 (6th Cir. 1939) (Jones Act); Nowery v. Smith, 69 F. Supp. 755 (E.D. Pa. 1946), aff'd mem., 161 F.2d 732 (3d Cir. 1947) (Jones Act); Steeley v, Kurn, 347 Mo. 74, 146 S.W.2d 578, aff'd mem., 313 U.S. 545 (1941) (FELA). The Supreme Court affirmed the Missouri Supreme Court's determination that the trial court erred in not directing a verdict for the defendant. This is the only FELA or Jones Act case under the Jamison rule in which the Court granted certiorari to review the sufficiency of the evidence. See also Love v. Baltimore \& Ohio R.R., 8 App. Div. 2d 944, 190 N.Y.S.2d 506 (1959); Zoccano v. Long Island R.R., 65 N.Y.S.2d 32 (Sup. Ct. 1946), aff'd, 272 App. Div. 949, aff'd, 298 N.Y. 553, 81 N.E.2d 96 (1948).

47 Kable v. United States, 169 F.2d 90 (2d Cir. 1948) (Jones Act). This case upheld dismissal of a complaint for want of an allegation that the assailant had authority over the injured seaman. 
assailant and the injured party considered. Other difficulties are encountered in attempting to maintain consistency among the decisions and establishing the proper relationship between the assault and battery cases that are decided apart from the breach of a common-law duty and those that are decided in connection with such a breach.

Judge Hand's opinion in Nelson v. American West-African Line, Inc.48 fully discussed the intent problem. In that case a drunken boatswain, who had authority over seamen, struck and injured a seaman, allegedly with the intention to get him to work. The assault and battery was committed a half hour before the injured seaman was to serve his watch, but the boatswain did have authority to call out hands when he thought it was necessary. Judge Hand, while reversing the directed verdict and remanding for a jury trial, noted, nevertheless, the difficulties confronting the jury: "The inquiry into the tangled mazes of a drunken boatswain's mind may be beyond the powers of a jury, but it is the fact upon which the case turns. . .."49 It is difficult to escape the conclusion that judges will direct verdicts because it is too difficult to determine intent and that juries will only speculate if they are asked to make the intent determination. 50

The use of the relationship between the assailant and the injured railroad worker or seaman as a test in cases applying the "furtherance" rule derives in part from use of an intent standard. Some of the cases hold that it is necessary that the assailant not only intend to further his employer's business but that he have actual authority over the injured worker or seaman. ${ }^{51}$ These cases claim to find authority in Jamison and Alpha S.S. Corp. which involved assaults and batteries by superiors upon subordinates. One explanation for this requirement is that it might be more credible that a superior officer or employee commits an assault and battery in the interests of his employer. This requirement may also be explained by reference to the old vice-principal rule,

4886 F.2d 730 (2d Cir.), cert. denied, 300 U.S. 665 (1937).

4986 F.2d at 732 .

50 Only one proposal has been made for the use of an objective test to determine intent. "The violence and persistence of the attack, as demonstrated by the seriousness of the injuries was strongly suggestive of a personal motivation. The outrageous quality of an employe's act may well be persuasive in considering whether his motivation was purely personal." Ochsrider v. Reading Co., 172 F. Supp. 830, 832 (E.D. Pa. 1959).

51 Walters v. Moore-McCormack Lines, Inc., 309 F.2d 191 (2d Cir. 1962) (Jones Act); Kable v. United States, 169 F.2d 90 (2d Cir. 1948) (Jones Act); Brailas v. Shepard S.S. Co., 152 F.2d 849 (2d Cir.), cert. denied, 327 U.S. 807 (1946) (Jones Act); Lykes Bros. S.S. Co. v. Grwoaugh, 128 F.2d 387 (5th Cir. 1942), modified, 130 F.2d (1942) (Jones Act). The Lykes Bros. case is criticized in Calameri, Assaults by Fellow Employees Under the FELA and the Jones Act, 28 FORDHAM L. REv. 449 (1959). The requirement that the assailant have authority over his victim has recently been disputed in Gibson v. Kennedy, 23 N.J. 150, 128 A.2d 480 (1957) (FELA). The New Jersey court noted that "ordinarily the fact that the assailant had authority to direct is evidential of the crucial fact that he acted within the scope of the employment and sought to further his employer's business...." Id. at 158, 128 A.2d at 485 . The court concluded, however, that the "crucial fact" may be proven in other ways. 
an exception to the fellow servant rule, which regarded superior officers and employees as acting in the place of their employers.

The tests of intent and relationship seriously undermine the effectiveness of a policy which seeks to shift the risk of loss in modern industrial and commercial situations. These tests do not refer to industrial and commercial conditions. They refer to the thoughts and attitudes of the assailant and formal lines of authority. Working under the same conditions some victims of assaults and batteries recover damages because their assailants acted under the misguided notion that they were serving the interests of their employers and others fail to recover because their assailant's intention or authority is unclear. Although it has been held that injuries from horseplay and sportive assaults and batteries are an inevitable by-product of groupings of workers and are hence compensable under workmen's compensation acts, 52 victims of the same behavior are not compensated in tort actions when the test of intent is applied because it is never the intention of the worker or seaman engaged in horseplay or committing a sportive assault to further his employer's business. 53

\section{IV}

Several conclusions can be drawn from this study of FELA and Jones Act assault and battery cases. When a railroad or shipowner has employed a worker whom it knew or had reason to know might commit assaults and batteries then liability may be imposed fairly and with good sense under the theory that the conditions prevalent on the railroads and aboard ships make an employee with such tendencies as dangerous as a malfunctioning machine. This theory is a variation of the rule applied under workmen's compensation which stresses the impact of work on the temper of all workers. ${ }^{54}$ It is well suited to the FELA and the Jones Act for it limits the employ-

52 Horovitz, Assaults and Horseplay Under Workmen's Compensation Laws, 41 IrL. L. REv. 311 (1946).

53 E.g., Copeland v. St. Louis-S.F. Ry., 291 F.2d 119 (10th Cir. 1961); Blunk v. Atchison, T. \& S. Fe Ry., 97 Cal. App. 2d 229, 217 P.2d 494 (1950) (FELA); Osment v. Pitcairn, 349 Mo. 137, 159 S.W.2d 666, cert. denied, 320 U.S. 79 (1942) (FELA); Steeley v. Kurn, 347 Mo. 74, 146 S.W.2d 578, aff'd mem., 313 U.S. 545 (1941). Compare Dull v. New York Cent. R.R., 196 F. Supp. 120 (E.D. Mich. 1961) (FELA), with Amann v. Northern Pac. Ry., 292 P.2d 753 (1955) (FELA).

54 "This view recognized that work places men under strains and fatigue from human and mechanical impacts, creating frictions which explode in myriads of ways, only some of which are immediately relevant to their tasks. Personal animosities are created by working together on the assembly line or in traffic. Others initiated outside the job are magnified to the breaking point by its compelled contacts. No worker is immune to these pressures and impacts upon temperament. They accumulate and explode over incidents trivial and important, personal and official. But the explosion point is merely the culmination of the antecedent pressures. That it is not relevant to the immediate task, involves a lapse from duty, or contains an element of volition or illegality does not disconnect it from them nor nullify their causal effect in producing its injurious consequences." Hartford Acc. \& Indem. Co. v. Cardillo, 112 F.2d 11, 17 (D.C. Cir.), cert. denied, 310 U.S. 649 (1949). 
er's liability to situations where the employer or his hiring agents might reasonably have been expected to act differently. In this manner the rule or liability under the FELA and the Jones Act retains the character of commonlaw negligence.

The theory treating an assault and battery as negligence and holding an employer liable for assaults and batteries committed in furtherance of his interests leads to decidedly undesirable results. The "furtherance" test of liability derives no support from either common-law negligence or the needs of industrial and commercial life. In fact, the difficulty of explaining why there is liability in some cases and not in others raises basic questions of fairness. If there is no basis in policy for distinguishing one case from another then the "furtherance" rule is not good law.

These conclusions form an argument against further application of the rule that assault and battery is FELA and Jones Act negligence. If the rule continues to be accepted, however, it then becomes necessary to determine whether it is proper to extend the rule to include false arrest and imprisonment.

It is true that in some respects the imposition of liability in the Slaughter case presents fewer difficulties than in the assault and battery cases. For a superior employee is more likely to have authority to request the arrest of another employee than to commit an assault and battery upon him. Nonetheless, extension of liability to false arrest disregards the policy behind allowing compensation for injuries caused by assault and battery. It is surprising that the court in Slaughter failed to take this into account, especially in light of its comment that "to bar the action [for assaults and batteries] would thwart the central purpose of the F.E.L.A.- to compensate railroad employees who suffer possibly disabling physical injury as a consequence of their employment."55

The interests protected by the common-law right to recover for false arrest and imprisonment are different from those protected by the right to recover for either negligence or assault and battery under the statutes. $56 \mathrm{~A}$ false arrest

55302 F.2d at 916 . For a discussion of compensation under the FELA, see the contribution of Professor Jaffe to a symposium on the FELA: Damages for Personal Injury: The Impact of Insurance, 18 LAW \& CONTEMP. PROB. 219 (1953). The FELA and the Jones Act, based on common-law negligence, allow some compensation for non-economic injuries, such as pain and suffering. Jaffe believes that this runs counter to the general policy of shifting the risk of loss in an industrial society. "[mt is doubtful that the pooled social fund of savings should be charged with the sums of indeterminate amount when compensation performs no specific economic function." Id. at 225. "II]f our basis of compensating injury is shifted implicitly or explicitly from fault to insurability there must be a reconsideration of the kinds of interest which are compensated and the degree of compensation for the interests which are compensible. It seems likely that as the goal becomes universal coverage of injury and disease, protection must tend to shrink toward the minimum level of economic loss." Id. at 235. Recovery has been allowed for a negligently caused disabling emotional injury, McMillan v. Western Pac. R.R., 54 Cal. 2d 841, 357 P.2d 449, 9 Cal. Rptr. 361 (1960), and for an occupational disease, Urie v. Thompson, 337 U.S. 163 (1949). Both conditions result in physical inability to work and consequently economic loss.

5649 VA. L. REv. 184, 190-91 (1963). 
action protects "the interest in freedom from confinement," 57 an interest that involves no loss from physical injury. It is thus more difficult to justify employer liability either as an inducement to the provision of safer working conditions or as a device to distribute risks. Although both assault and battery and false arrest and imprisonment are intentional torts, there is no basis for according them like treatment for the purpose of FELA and Jones Act liability. The test of the appropriateness of liability should be found in the nature of the interests protected rather than the artificial use of common-law intentional tort categories.

Thus neither premise of the Slaughter argument is strong. Assaults and batteries should not be considered negligence under the FELA and the Jones Act although there are situations in which recovery is proper because the duty to provide a safe place to work has been breached. Although false arrest and imprisonment is like assault and battery in that it is technically an intentional tort, it is sufficiently different from assault and battery to preclude the extension of the erroneous rule that assault and battery is FELA and Jones Act "negligence." Therefore, it seems to follow that FELA and Jones Act negligence should not be expanded to include false arrest and imprisonment.

S7 1 HARPER \& JAMES, TORTS $\$ 3.6(1956)$. There is no such tort as negligent false arrest and imprisonment. If someone is negligently confined he must show the invasion of an interest other than freedom from confinement. Id. §3.7. Therefore, the argument in Jamison that the interests protected by the action for negligence should also be protected when they are invaded by assault and battery does not apply to false arrest and imprisonment because the interest protected by the action for false arrest and imprisonment is not thought to be invaded by negligence. 